\title{
DURABILTY OF 25 LOCAL SPECIFIC WOOD SPECIES FROM JAVA PRESERVED WITH CCB AGAINST MARINE BORERS ATTACK
}

\author{
Mohammad Muslich ${ }^{1,2}$ and Sri Rulliaty ${ }^{1}$
}

\begin{abstract}
This study was conducted to provide basis information of the 25 local specific wood species indigenous from Java treated by copper bichromated boron (CCB). The full-cell process for 2 hours and 150 psi during the pressure-keeping period was employed. The IUFRO method was applied for the determination of wood treatability class. The treated and untreated wood specimens were tied together using plastic cord, arranged into a raft like assembly, and then exposed for 3, 6, and 12 months to the brackish water situated at Rambut Island's coastal area. The Nordic Wood Preservation Council (NWPC) standard No.1.4.2.2/75 was used to determine the intensity of marine borer infestation. The results revealed that 19 out of those 25 species were classified as easy to be preserved, four species as moderate, and the remaining two were difficult to be preserved. Those 19 species, i.e. Tamarindus indica L., Diplodiscus sp., Ficus variegate R.Br., Ehretia acuminata R.Br., Meliocope lunu-ankenda (Gaertn) T.G. Hartley, Colona javanica B.L., Pouteria duclitan Bachni., Stercularia oblongata R.Br., Ficus vasculosa Wall ex Miq., Callophyllum grandiflorum JJS., Turpinia sphaerocarpa Hassk., Neolitsea triplinervia Merr., Acer niveum Bl., Sloanea sigun Szysz., Castanopsis acuminatissima A.DC., Cinnamomum iners Reinw. Ex Blume., Litsea angulata Bl., Ficus nervosa Heyne., and Horsfieldia glabra Warb. were more permeable implying that the $\mathrm{CCB}$ retention and penetration were greater and deeper. Hymeneae carboril. L., Litsea odorifera Val., Gironniera subasqualis Planch., and Lindera polyantha Boerl. were moderately permeable. Castanopsis tunggurut A.DC. and Azadirachta indica Juss. were the least permeable judging that the CCB retention and penetration were lowest and shallowest. The treated wood specimens in this regard were able to prevent marine borers attack. Meanwhile, the untreated specimens were susceptible to marine borers attack, except Azadirachta indica. The attacking borers consecutively are Martesia striata Linne that belongs to the Pholadidae family; and Teredo bartschi Clapp., Dicyathifer manni Wright., and Bankia cieba Clench. to the Terdinidae family.
\end{abstract}

Keywords: Local specific wood species, CCB, full cell process, marine borers

\section{INTRODUCTION}

The resistance of wood to marine borer attack varies from one species to others. This is mainly caused by the variation in natural properties of the wood species. Bianchi (1933) and Southwell and Bultman (1971) stated that the resistance of wood to marine borers attack depends on silica content, density or hardness of wood, and the content

\footnotetext{
${ }^{1}$ Center for Forest Products Research and Development, Jl. Gunung Batu 5, Bogor 16000, Indonesia

2 Corresponding Author. E-mail:mohammad_muslich@yahoo.co.id
} 
of extractives which have a poisonous property. The suitability of non-durable wood species exposed to the condition under high risk of marine borers attack depends on the treatability of the species themselves. Some wood species are highly treatable, while some others are refractory. Unfortunately, it is impossible to preserve all timber species with equally satisfied results. Some species prevent preservatives from entering even under high pressures, while others even allow deep penetration.

Timber in the sea and brackish water is frequently subject be attacked by marine borers. Damage caused by these boring organisms is practically worldwide. Even, high temperature of tropical seas enables them to breed in these waters all the year round. The rapidity of attack depends upon local conditions and the kinds of borers present (Mata and Siriban, 1972). Piles of non resistant timber can become heavily infested within three months and hence lose all their strength in six months.

As the relevance, this study is intended to provide basic information on the treatment of 25 local specific wood species from Java using a CCB preservative. The information is beneficial to the assessment of those wood species for ship building or marine construction. Accordingly, the durability of wood species to preservative retention and penetration, and the intensity of marine borer attack were evaluated in this study.

\section{MATERIALS AND METHODS}

Twenty five local specific wood species originated from West Java and East Java (Table 1) were selected and then used in the experiment.

Table 1. The selected wood specimen from West Java and East Java

\begin{tabular}{cll}
\hline No. & \multicolumn{1}{c}{ Local name } & \multicolumn{1}{c}{ Scientific name } \\
\hline 1. & Marasi & Hymeneae carboril \\
2. & Asem jawa & Tamarindus indica \\
3. & Balobo & Diplodiscus \\
4. & Kundang & Ficus variegata \\
5. & Ki kendal & Ehretia acuminata \\
6. & Huru gading & Litsea odorifera \\
7. & Ki sampang & Meliocope lunu-ankenda \\
8. & Sampora & Colona javanica \\
9. & Nyatoh putih & Pouteria duclitan \\
10. & Ki hantap & Sterculia oblongata \\
11. & Ki kuya & Ficus vasculosa \\
12. & Ki lubang & Callophyllum grandiflorum \\
13. & Ki bancet & Turpinia sphaerocarpa \\
14. & Ki bulu & Gironniera subasqualis \\
\hline
\end{tabular}


Table 1 (continued)

\begin{tabular}{cll}
\hline No. & \multicolumn{1}{c}{ Local name } & \multicolumn{1}{c}{ Scientific name } \\
\hline 15. & Huru mentek & Lindera polyantha \\
16. & Huru kacang & Neolitsea triplinervia \\
17. & Tunggeureuk & Castanopsis tunggurut \\
18. & Ki endog & Acer niveum \\
19. & Beleketebe & Sloanea sigun \\
20. & Mimba & Azadirachta indica \\
21. & Ki hiur & Castanopsis acuminatissima \\
22. & Huru pedes & Cinnamomum iners \\
23. & Huru koja & Litsea angulata \\
24. & Ki kanteh & Ficus nervosa \\
25. & Kelapa ciung & Horsfieldia glabra \\
\hline
\end{tabular}

Thirty-five (35) smoothly planed wood specimens of $2.5 \mathrm{~cm}$ by $5 \mathrm{~cm}$ by $30 \mathrm{~cm}$ were prepared for each species, totaling 875 specimens for the over all 25 wood species. A one centimeter diameter hole was made at the middle on the surface $(5 \mathrm{~cm}$ by $30 \mathrm{~cm})$ of each specimen (Figure 1).

Five hundred out of 875 specimens were impregnated with $3 \%$ copper bichromated boron (CCB) using the full-cell pressure for 2 hours at 150 psi during the pressurekeeping period. In this study $\mathrm{CCB}$ was used in paste form with $95 \%$ purity containing $\mathrm{CuSO}_{4} 5 \mathrm{H}_{2} \mathrm{O}$ as active agent (33\%), $\mathrm{K}_{2} \mathrm{Cr}_{2} \mathrm{O}_{7}(40 \%)$, and $\mathrm{H}_{3} \mathrm{BO}_{3}(24 \%)$. The retention was calculated for its weight differences before and after CCB treatment. Afterwards, five treated wood specimens of each species were selected for assessment of penetration. These specimens were cross cut at $5 \mathrm{~cm}$ lengthwise distance from their both ends. The cut surface area was subsequently sprayed with reagents for the determination of $\mathrm{CCB}$ penetration. The inward extent of CCB penetration into wood specimen was conducted by the spot test for $\mathrm{Cu}$ or copper containing preservative (e.g. $\mathrm{CCB}$ ) and the spraying reagent used was chrome azurol solution. The present of $\mathrm{Cu}$ can be determined when the color of the wood turns into dark blue. The IUFRO method (Smith and Tamblyn, 1970) was applied for the determination of wood treatability classes (Table 2).

Table 2. Classification of wood treatability

\begin{tabular}{ll}
\hline Class & Penetration \\
\hline A (easy) & over $90 \%$ \\
B (moderate) & $50-90 \%$ \\
C (difficult) & $10-50 \%$ \\
D (very difficult) & less than $10 \%$ \\
\hline
\end{tabular}

Source: Smith and Tamblyn (1970) 
Another five treated samples from each species were exposed into marine borers for certain duration. Five untreated wood specimens of each species were also prepared as control. The treated and untreated wood specimens were tied together using plastic rope (cord), arranged into a raft like assembly (Figure 1), and then exposed to the brackish water at Rambut Island's coastal waters area for 3,6 and 12 months. At the end of the experiment, the specimens were split parallel to the longest dimension of specimen through its thickness into two parts in similar size to determine marine borer infestation. The Nordic Wood Preservation Council (NWPC) Standard No. 1.4.2.2/75 (Norman and Henningson, 1975) was used to determine the intensity of infestation. The marine borer attacks were detected from the traces of boring holes, form of cutting, and pallet on the infested samples. To evaluate the intensity of such borer attack, the criteria as adopted were shown in Table 2.

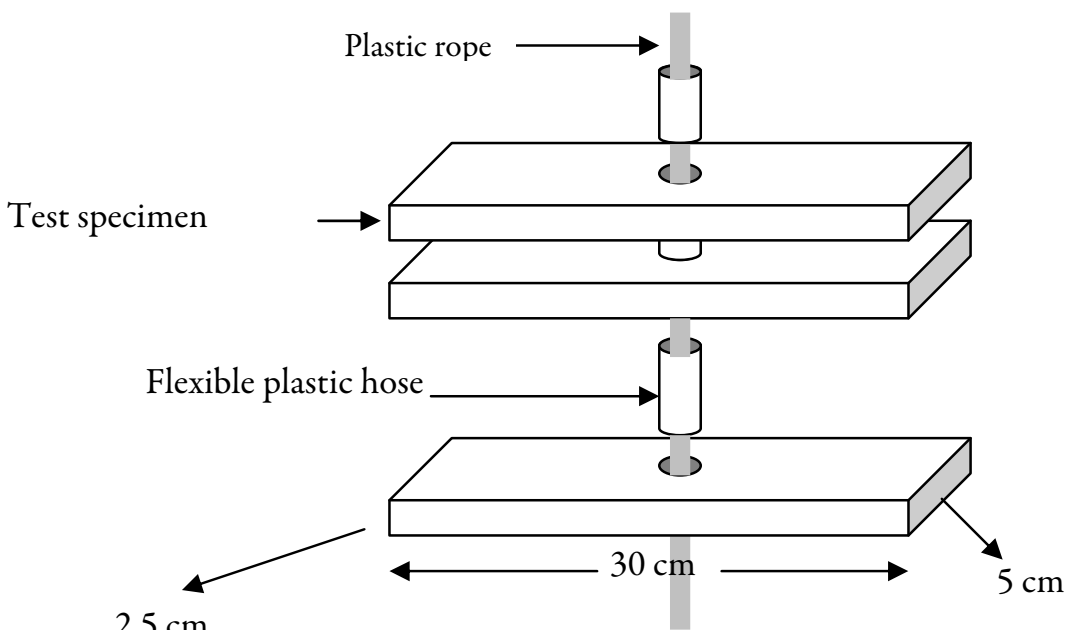

Figure 1. The arrangement of wood specimens into a raft-like assembly for marine borer attack tests

Table 3. The intensity of borer attack

\begin{tabular}{lc}
\hline Wood condition & Intensity of borer attack \\
\hline No attack & $0=<1 \%$ \\
Light attack & $1 / 3=1-33 \%$ \\
Medium attack & $2 / 3=34-66 \%$ \\
Heavy attack & $1=>67 \%$ \\
\hline
\end{tabular}


Further, the species of marine borer that attacked the specimen could be identified from the traces of their boring holes. Such traces could be observed by cutting the pallet of the attacked specimen. The marine borers were identified in accordance with the identification key for marine borers (Turner, 1971).

\section{RESULTS AND DISCUSSION}

\section{A. Resistance of Untreated Wood Species}

Results of the experiment reveal that intensity of marine borer attack varied depending on the duration of specimen exposure to sea waters. Most of the untreated specimens were severely attacked by marine bores after 3 -month exposure, particularly kundang (F. variegata BL.), ki hantap (S. oblongata), ki kanteh (F. nervosa), huru koja (L. angulata), ki sampang (M. lunu-ankenda), tunggeureuk (C. tunggurut), huru kacang ( $N$. triplinervia), ki endog (A. niveum), and huru pedes (C. iners). These nine wood species were very susceptible to marine borers attack. Medium attack was frequently found on asem jawa ( $T$. indica), balobo (Diplodiscus), huru gading (L. odorifera), sampora $(C$. javanica), nyatoh putih (P.duclitan), ki kuya (F. vasculosa), ki lubang (C.grandiflorum), ki bancet (T. sphaerocarpa), ki bulu (G. subasqualis), beleketebe ( $S$. sigun), ki hiur (C. acuminatissima), and kelapa ciung (H. glabra). Meanwhile, the remaining wood species namely mimba ( $A$. indica), marasi (Hymeneae carboril) and ki kendal (E. acuminata) were light attack. Among 25 local untreated wood species from Java, only mimba $(A$. indica) was resistant to marine borers for 6 months. This wood species was categorized into durability class II, which is suitable for marine construction (Muslich and Sumani, 2005). The intensity of marine borer infestation is shown in Table 3.

The difference in wood resistance against borer attack is due to the difference in natural properties of untreated wood species. Silica content, wood strength or density and poisonous extractive substances could reduce or inhibit marine borer attack (Bianchi, 1933; Gonggrijp, 1932; Southwell and Bultman, 1971). Silica could minimally reduce the marine borer attack by 0.5 percent. Bianchi (1933) carried out a study on resistance of several wood species against marine borers in Indonesia. Results of this study showed that mimba was the most durable of the other wood species. One of the possible reasons is the presence of its poisonous extractive substance. Ruskin (1993) said that the extractives in mimba wood consist of azadirachtin, salanin, methan triol, nimbin and nimbidin. Furthermore, Senrayan (1997) stated that the extractive in mimba inflected the disturbance on the attacking diseases and pest growth process, but did not combat them quickly. Azadirachtin has role as ecdyson blocker or kind of substance for inhibiting ecdyson hormone in metamorphose process, which ultimately brings about mortal effect (Chiu, 1988). Selanin affords a function as anti-feedant to reduce the destructive force of organism attack (Ruskin, 1997). Meliantriol serves as repellant that makes the microorganism hesitate to approach wood (Sudarmadji, 1991). Then, nimbin 
and nimbinidin have been utilized as anti microorganisms like antivirus and bactericide, which can act as phytopesticide (Ruskin, 1997).

Table 4. The intensity of marine borers attack on test sample (specimens)

\begin{tabular}{|c|c|c|c|c|c|c|c|c|}
\hline \multirow{3}{*}{ No. } & \multirow{3}{*}{ Wood species } & \multirow{3}{*}{$\begin{array}{c}\text { Specific } \\
\text { gravity }\end{array}$} & \multicolumn{6}{|c|}{ Attack intensity (\%) } \\
\hline & & & \multicolumn{2}{|c|}{3 months ${ }^{1)}$} & \multicolumn{2}{|c|}{6 months $^{1)}$} & \multicolumn{2}{|c|}{12 months ${ }^{1)}$} \\
\hline & & & Control & Treated $^{2)}$ & Control & Treated $^{2)}$ & Control & Treated $^{2)}$ \\
\hline 1. & Marasi (H. carboril) & 0.87 & 25 & 0 & 55 & 0 & 70 & 5.5 \\
\hline 2. & Asem jawa (T. indica) & 0.92 & 40 & 0 & 65 & 0 & $\mathrm{x}$ & 0 \\
\hline 3. & Balobo (Diplodiscus) & 0.73 & 35 & 0 & 50 & 0 & 75 & 0 \\
\hline 4. & Kundang (F. variegata) & 0.29 & 70 & 0 & 90 & 0 & $\mathrm{x}$ & 0 \\
\hline 5. & Ki kendal (E. acuminata) & 0.61 & 25 & 0 & 55 & 0 & 75 & 0 \\
\hline 6. & Huru gading (L. odorifera) & 0.51 & 45 & 0 & 80 & 0 & $\mathrm{x}$ & 2 \\
\hline 7. & Ki sampang (M. lunu-ankenda) & 0.43 & 67 & 0 & 85 & 0 & $\mathrm{x}$ & 0 \\
\hline 8. & Sampora (C. javanica) & 0.47 & 50 & 0 & 70 & 0 & 85 & 0 \\
\hline & Nyatoh putih (P. duclitan) & 0.56 & 40 & 0 & 60 & 0 & 80 & 0 \\
\hline 10. & Ki hantap (S. oblongata) & 0.36 & 70 & 0 & 85 & 0 & $\mathrm{x}$ & 0 \\
\hline 11. & Ki kuya (F.vasculosa) & 0.45 & 50 & 0 & 75 & 0 & 90 & 0 \\
\hline 12. & Ki lubang (C. grandiflorum) & 0.58 & 40 & 0 & 55 & 0 & 80 & 0 \\
\hline & Ki bancet (T. sphaerocarpa) & 0.55 & 45 & 0 & 70 & 0 & 80 & 0 \\
\hline & Ki bulu (G. subasqualis) & 0.51 & 50 & 0 & 75 & 0 & 90 & 2.5 \\
\hline 15. & Huru mentek (L. polyantha) & 0.81 & 20 & 0 & 35 & 0 & 70 & 5 \\
\hline 16. & Huru kacang (N. triplinervia) & 0.46 & 65 & 0 & 85 & 0 & $\mathrm{x}$ & 0 \\
\hline 17. & Tunggeureuk (C. tunggurut) & 0.44 & 65 & 0 & 85 & 0 & $\mathrm{x}$ & 1.5 \\
\hline 18. & $\mathrm{Ki}$ endog $(A$. niveum $)$ & 0.49 & 65 & 0 & 85 & 0 & $\mathrm{x}$ & 0 \\
\hline 19. & Beleketebe (S. sigun) & 0.79 & 35 & 0 & 55 & 0 & 75 & 0 \\
\hline 20. & $\operatorname{Mimba}(A$. indica) & 0.82 & 10 & 0 & 25 & 0 & 45 & 2 \\
\hline 21. & Ki hiur (C. acuminatissima) & 0.74 & 45 & 0 & 65 & 0 & 80 & 0 \\
\hline 22. & Huru pedes (C. iners) & 0.57 & 66 & 0 & 80 & 0 & $\mathrm{x}$ & 0 \\
\hline 23. & Huru koja (L. angulata) & 0.45 & 68 & 0 & 85 & 0 & $\mathrm{x}$ & 0 \\
\hline 24. & Ki kanteh (F.nervosa) & 0.35 & 70 & 0 & 90 & 0 & $\mathrm{x}$ & 0 \\
\hline 25. & Kelapa ciung (H. glabra) & 0.58 & 55 & 0 & 80 & 0 & $\mathrm{x}$ & 0 \\
\hline
\end{tabular}

Remarks: $\quad \mathrm{x}=$ completely destroyed

1) $=$ duration of exposure

2) = with CCB (copper, bichromated, boron) preservative 


\section{B. The Effectiveness of CCB}

The CCB preservative owes their permanence among them after being in contact with the cell wall, thus producing the active ingredients for cleaning. This coprecipitation is brought about by addition of chromates (Findlay, 1975). The addition of copper, especially copper sulfate affords toxicity class I being highly toxic. Because of its potentially harmful effects on some endangered aquatic species, surface-water use may require a permit in some places. Copper sulfate is often found in combination with other pesticides and very toxic to human beings at high levels. Copper sulfate is toxic to aquatic invertebrates, such as crab, shrimp, and oysters. Higher concentration of this copper-containing chemical causes some behavioral changes, such as secretion of mucous, and discharge of eggs and embryos (Wilkinson, 1979).

Most of the treated specimens were resistant for 12 months. After twelve months, only a few specimens were damaged. Light attack was found on marasi, huru gading, ki bulu, huru mentek, tunggeureuk, and mimba species. This indicates that CCB preservative was more effective for the entire other wood species such as kundang, ki hantap, ki kanteh, huru koja, etc. The difference in the resistance of treated wood against marine borers is due to the difference in retention and penetration of CCB. $\mathrm{CCB}$ retention and penetration for each wood species can be seen in Table 4. Intensity of marine borer infestation on untreated and treated wood species after six and twelve month exposure in the sea can be seen in Figures 2 and 3.

Table 3 and 4 also show that the wood species that were highly susceptible, in fact were also easier to be preserved than the other species that more resistant to the marine borers attack. Low retention and penetration will easily be washed out by sea water, so that the wood samples will easily attacked by marine borers. In this case, asem jawa $(T$. indica), balobo (Diplodiscus), kundang (F. variegata BL.), ki kendal (E. acuminata), etc. being easily preserved by CCB were more resistant to the marine borers attack than the other difficulty preserved wood specimens. Therefore, the CCB preservative retention was high and its penetration was also deeper. This means that in case kundang, ki hantap, ki kanteh, huru koja etc. do not have high silica content, strength or density and poisonous extractive substances, the attack by marine borers could be reduced by high preservative treatment with high retention and deep penetration. The attack of marine borers on other wood species could also be reduced as long as the wood species contain poisonous extractive substances. Bianchi (1933) proved that teruntum wood (Lumnitzera littorea Voight.) and bungur wood (Lagerstromia spiciosa Pers.) were resistant to marine borers attack although they do not contain silica. 
Table 5. Retention $\left(\mathrm{kg} \mathrm{m}^{-3}\right)$ and penetration (\%) of CCB in twenty five local specific wood species originated from Java

\begin{tabular}{|c|c|c|c|c|}
\hline No. & Wood species & Retention $\left(\mathrm{kg} \mathrm{m}^{-3}\right)$ & $\begin{array}{l}\text { Penetration } \\
(\%)\end{array}$ & $\begin{array}{c}\text { Treatability } \\
\text { class }\end{array}$ \\
\hline 1. & Tunggeureuk (C. tunggurut) & 2.6 & 47.4 & III (difficult) \\
\hline 2. & $\operatorname{Mimba}(A$. indica) & 5.7 & 41.3 & III (difficult) \\
\hline 3. & Ki bulu (G. subasqualis) & 6.4 & 70.6 & II (moderate) \\
\hline 4. & Marasi (H. carboril) & 7.8 & 55.3 & II (moderate) \\
\hline 5. & Huru gading (L. odorifera) & 9.0 & 72.1 & II (moderate) \\
\hline 6. & Huru mentek (L.polyantha) & 9.3 & 84.9 & II (moderate) \\
\hline 7. & Asem jawa (T. indica) & 11.0 & 98.0 & I (easy) \\
\hline 8. & Ki lubang (C. grandiflorum) & 11.5 & 97.1 & I (easy) \\
\hline 9. & Huru kacang (N. triplinervia) & 12.2 & 94.5 & I (easy) \\
\hline 10. & Ki kendal (E. acuminata) & 13.2 & 97.8 & I (easy) \\
\hline 11. & Sampora (C. javanica) & 13.3 & 92.2 & I (easy) \\
\hline 12. & Ki sampang (M. lunu-ankenda) & 13.8 & 98.5 & I (easy) \\
\hline 13. & Nyatoh putih (P. duclitan) & 14.4 & 91.3 & I (easy) \\
\hline 14. & Balobo (Diplodiscus) & 14.5 & 91.1 & I (easy) \\
\hline 15. & Huru koja (L. angulata) & 15.2 & 98.6 & I (easy) \\
\hline 16. & Huru pedes (C. iners) & 15.2 & 90.3 & I (easy) \\
\hline 17. & Beleketebe (S. sigun) & 15.4 & 100.0 & I (easy) \\
\hline 18. & Ki bancet (T. sphaerocarpa) & 16.3 & 100.0 & I (easy) \\
\hline 19. & Ki hiur (C. acuminatissima) & 16.4 & 93.6 & I (easy) \\
\hline 20. & Ki kuya $(F$. vasculosa $)$ & 16.5 & 97.8 & I (easy) \\
\hline 21. & Kelapa ciung (H. glabra) & 17.1 & 98.9 & I (easy) \\
\hline 22. & Ki hantap (S. oblongata) & 17.2 & 100.0 & I (easy) \\
\hline 23. & $\mathrm{Ki}$ endog (A. niveum) & 17.4 & 100.0 & I (easy) \\
\hline 24. & Kundang $(F$ variegata $)$ & 17.7 & 100.0 & I (easy) \\
\hline 25. & Ki kanteh (F. nervosa) & 18.7 & 100.0 & I (easy) \\
\hline
\end{tabular}




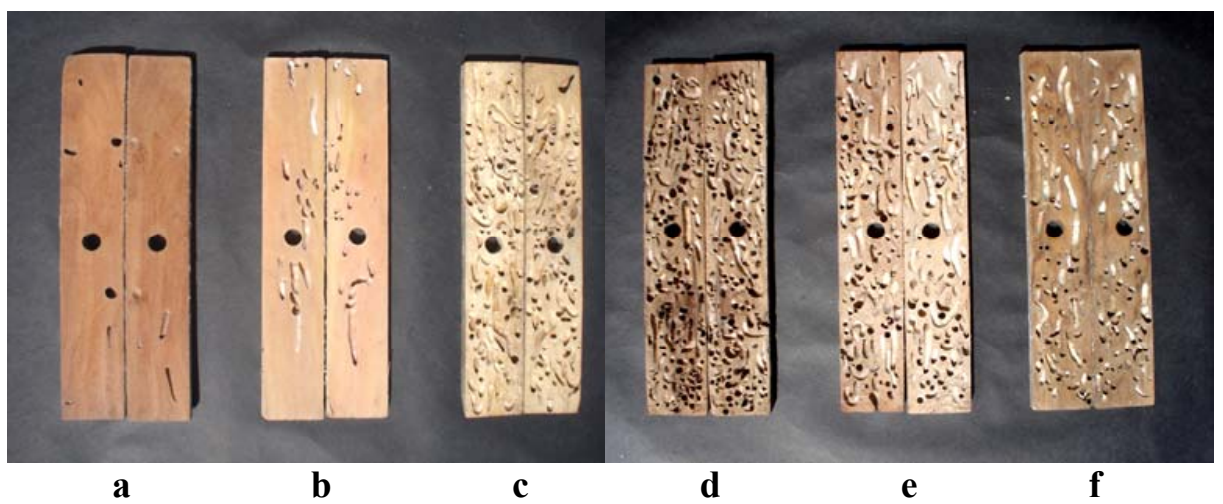

Figure 2. Intensity of marine borer infestation on untreated wood species after six month exposure in the sea (brackish water): a. mimba; b. huru mentek; c. Beleketebe; d. Huru kacang; e. Ki endog; f. Tunggeureuk

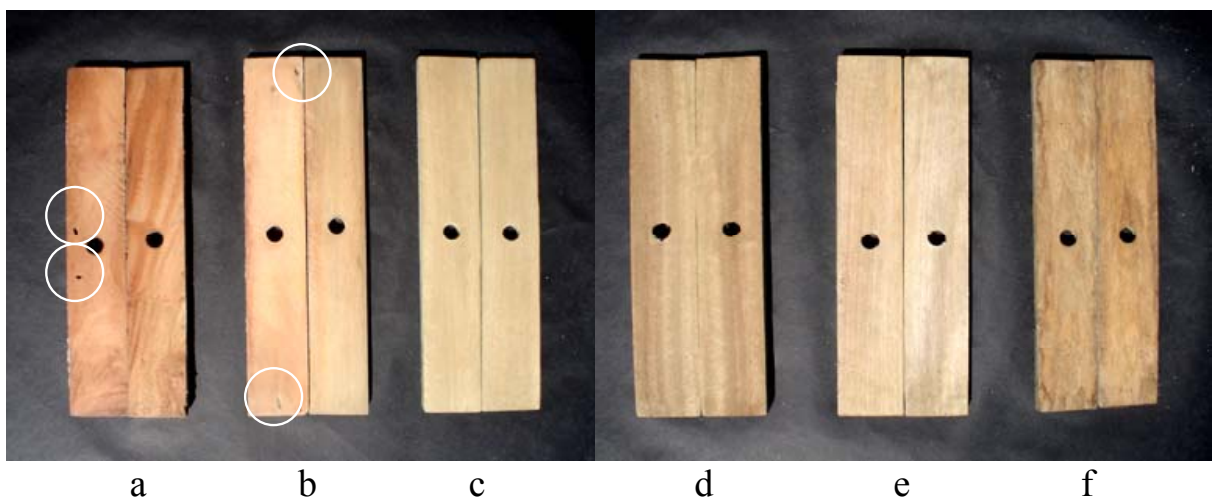

Figure 3. Intensity of marine borer infestation on CCB treated wood species after twelve month exposure in the sea: a. mimba; b. huru mentek; c. Beleketebe; d. Huru kacang; e. Ki endog; f. Tunggeureuk; white circle = attack signs.

Most of the twenty five local specific wood species from Java exhibit a wide differences in retention and penetration. Results revealed that two of this species were classified as difficult to be preserved with CCB, 4 species as moderate, and 19 species as easy. Mimba ( $A$. indica) and tunggeureuk (C. tunggurut) were not permeable, so that the retention and penetration were lower and shallow. Retention and penetration in these two species were $5.7 \mathrm{~kg} \mathrm{~m}^{-3}$ and $41.3 \%$; and $2.6 \mathrm{~kg} \mathrm{~m}^{-3}$ and $47,4 \%$, respectively. Those wood species were categorized into treatabilty class III or difficult treatability. Moderate treatability (class II) was found on ki bulu (G. subasqualis), huru mentek (L. polyantha), 
huru gading (L. odorifera), and marasi ( $H$. carboril). Retention and penetration in those wood species were $6.4 \mathrm{~kg} / \mathrm{m}^{3}$ and $70.6 \% ; 9.3 \mathrm{~kg} / \mathrm{m}^{3}$ and $84.9 \% ; 9.0 \mathrm{~kg} / \mathrm{m}^{3}$ and $72.1 \%$; and $7.8 \mathrm{~kg} / \mathrm{m}^{3}$ and $55.3 \%$, respectively. The test that lasted for 12 months at the sea showed that the wood species that were difficult to preserve, had started to be attacked by marine borers. Meanwhile, for the remaining 19 wood species that were easily preserved, retention of CCB in the wood of above $10 \mathrm{~kg} / \mathrm{m}^{3}$ and penetration of more than $90 \%$ still showed no signs of attack.

\section{Identification of Marine Borers}

Marine borers which had attacked the untreated specimens in the sea of Rambut Island consisted of Martasia striata under Pholadidae family, and Teredo bartschi, Dicyathifer manni, and Bankia cieba Clench/Turner both under Teredinidae family. There were no symptoms of crustacean infestation on those specimens. However, many crustaceans were found clinging to the specimens when they were taken from sea. These crustaceans belong to Sphaeroma sp. under Sphaeromatidae family.

\section{CONCLUSION}

Most of the 25 local wood species from Java as represented by untreated specimens were severely attacked by the marine bores after 3-month exposure in the sea of Rambut Island, except mimba (Azadirachta indica). This was caused by differences in chemical components inside the wood. Most of the specimens treated with copperbichromated boron (CCB) by 150 psi full-cell process for two hours, were resistant for 12 months. After twelve months, yet only a few specimens were damaged. The difference in the resistance of treated wood against marine borers is due to the difference in retention and penetration of preservative. The attacking borers consisted of Martesia striata. of Pholadidae family, Teredo bartschi, Dicyathifer manni, and Bankia cieba. of Terdinidae family. The Crustaceans found on the specimens were Sphaeroma sp. of the Sphaeromatidae family.

\section{REFERENCES}

Bianchi, A.T.J. 1933. The resistance of some Netherlands East Indian Timbers against the attack of shipworms (Teredo). Fith Pacific Congress, Canada. Pp. 3903-3906.

Chiu, S.F. 1988. Recent advances in research on botanical insecticides in China. South China Agricultural University. Guangzhou. pp. 69-77.

Findlay. W.P.K. 1975. Preservative of Timber in The Tropic. Martinus Nijhoff/Dr W.Junk Publisher. Dordrect.

Gonggrijp, J.W. 1932. Gegevens Betreffende een Onderzoek Naar NederlandschIndische Houtsoorten, Welke Tegen den Pealworm Bostand Zijn. Mededeeligen van het Boschbouwproeftation. Bogor. 
Mata, P.G. and F.R. Siriban. 1972. Resistance of wood to marine borers. Technical Note, No.171. FORPRIDECOME, College, Laguna 3720. Philippines.

Muslich, M. and G. Sumarni. 2005. Keawetan 200 jenis kayu Indonesia terhadap penggerek di laut. Jurnal Penelitian Hasil Hutan Bogor 23(3):163-176. (In Indonesia with English abstract.

Norman, E. and B. Henningson. 1975. Description of a trial with wood preservatives against marine borers wood boring organisms. Document No. IRG/WP/412, Stockholm, Sweden.

Ruskin, F.R. 1993. Neem: a Tree for Solving Global Problems. National Academy Press. Washington, D.C.

Senrayan, R. 1997. Prospects and challenges in production and use of neem pesticides. Proceedings of The National conference on Pesticides with emphasis on Neem, 24-25 November 1997. Surabaya, Indonesia.

Smith, D.N.R. and N. Tamblyn. 1970. Proposed Scheme for An International Standard Test for The Resistance of Timbers to Impregnation With Preservatives. Ministry of Technology, Forest Product Research Laboratory. New Zealand.

Southwell, C.R. and J.D. Bultman. 1971. Marine borers resistance of untreated woods over long periods of immersion in tropical waters. Biotropica 3(1): 81-107.

Sudarmadji, D. 1991. Mimba, insektisida alami. Trubus IV (44): 20-21.

Turner, R.D. 1971. Identification of Marine Wood-Boring Mollusks: Marine Borers, Fungi and Fouling Organisms of Wood. Organization for Economics Cooperation and Development. Paris.

Wilkinson, J.G. 1979. Industrial Timber Preservation. Associated Business Press. London. 